ника // Промышленная ботаника. 2012. Вып. 12. C. $67-74$

9. Приходько С.А., Остапко В.М., Купрюшина Л.В. Синтаксономічна різноманітність рослинності Південного Сходу України в аспекті синфітосозології // Промышленная ботаника. 2012. Вып. 12. С. 53-60.

10. Глухов О.3., Шевчук О.М., Кохан Т.П. Наукові основи відновлення трав'яних фітоценозів в степовій зоні України. Донецьк: Вебер, 2008. 198 с.

11. Шевчук О.М. Флористична диференціація пасовищних екосистем як основа їх збереження та вітворення: автрореф. дис. ... д-ра біол. наук. Київ, 2013. $40 \mathrm{c}$.

12. Шевчук О.М. Роль пасовищних екосистем в збереженні біорізноманітності // Промышленная ботаника. 2012. Вип. 12. С. 61-66.
13. Виноградов Б.В. Основы ландшафтной экологии. М.: ГЕОС, 1988. 418 с.

14. Остапко В.М., Шевчук О.М., Приходько С.А. К вопросу классификации экосистем юго-востока Украины // Самарский научный вестник. 2016. № 1 (14). C. 41-47.

15. Бурда Р.И. Антропогенная трансформация флоры. Киев: Наук. думка, 1991. 168 с.

16. Остапко В.М. Эйдологические, популяционные и ценотические основы фитосозологии на юговостоке Украины. Донецк: Лебедь, 2005. 408 с.

17. Флороценотичні та популяційні основи моніторингу, збереження та використання фітобіоти / Звіт про науково-дослідну роботу (проміжний) / Донецький ботанічний сад НАН України; кер. В.М. Остапко. 2009 р. № ДР 0106U004518. Донецьк, 2009. 98 с.

\title{
SYNTAXONOMIC DIVERSITY OF PASTURE ECOSYSTEMS VEGETATION IN SOUTH-EAST UKRAINE
}

V.M. Ostapko, doctor of biological sciences, professor,

head of the Department of Natural Flora and Nature Conservation, deputy director for scientific work Donetsk Botanical Garden, Donetsk (Donetsk People's Republic)

O.M. Shevchuk, doctor of biological sciences, head of the Laboratory of Aromatic and Medicinal Plants Nikita Botanical Garden - National Research Center of Russian Academy of Sciences, Yalta, u.t.s. Nikita (Russia)

S.A. Prikhodko, candidate of biological sciences, senior researcher of the Department of Natural Flora and Nature Conservation, director Donetsk Botanical Garden, Donetsk (Donetsk People's Republic)

\footnotetext{
Abstract. This work presents research data on pasture ecosystems vegetation in south-east Ukraine. This survey was carried out during 1998-2011 by route and semi-permanent methods. All botanical and geographical chorions of lower level within the territory of our region were explored. The representation of vegetation formations and associations were studied in following pasture steppe ecosystems: watershed ecosystems with differentiated black soil (43 formations, 425 associations), ravine-gully ecosystems with eroded black soil (81 formations, 750 associations), ravine-gully ecosystems with eroded to granite black soil (48 formations, 293 associations), ravine-gully ecosystems with eroded to limestone black soil (39 formations, 355 associations), above flood-plain terraced ecosystems with cretaceous soil (46 formations, 220 associations), above flood-plain terraced sandy ecosystems ( 24 formations, 140 associations). It is shown that syntaxonomic diversity of natural pasture ecosystems vegetation is dominantly represented by 1029 associations and 178 formations (37\% and 33\% from associations and formations of regional native vegetation). As far as steppe ecosystems are concerned, 920 associations and 147 formations are registered $(33 \%$ and $27 \%$ from associations and formations of regional native vegetation). As for meadow ecosystems, we registered 424 associations and 80 formations ( $15 \%$ and $14 \%$ from native associations and formations, respectively). The highest syntaxonomic diversity is characteristic of ravine-gully ecosystems on eroded to loess black soil, the lowest diversity of all the steppe ecosystems is reported for above flood-plain terraced sandy steppes. Among meadows, vegetation of salt and marsh meadows has the lowest diversity.

Keywords: south-east Ukraine; vegetation; syntaxonomic diversity; phytocenotic diversity; dominant vegetation classification; formation; association; steppe ecosystems; pasture ecosystems; watershed ecosystems; ravine-gully ecosystems; above-flood plain terraced ecosystems.
}

УДК 581.9

\section{ПЕТРОФИТНО-СТЕПНЫЕ СООБЩЕСТВА ГОРЫ МОГУТОВА (ЖИГУЛЁВСКАЯ ВОЗВЫШЕННОСТЬ)}

(C) 2016

Л.В. Сидякина, аспирант лаборатории проблем фиторазнообразия

B.M. Васюков, кандидат биологических наук, научный сотрудник лаборатории проблем фиторазнообразия

С.В. Саксонов, доктор биологических наук, профессор,

заместитель директора по научной работе, заведующий лабораторией проблем фиторазнообразия

Институт экологии Волжсского бассейна РАН, Тольятти (Россия)

Аннотация. Гора Могутова - куполообразный эрозионный останец на севере Жигулевской возвышенности, расположена в национальном парке «Самарская Лука». Сообщества петрофитных степей формируются на известняковых обнажениях крутых склонов западной, южной и восточной экспозиций горы Могутова. Описа- 
ны петрофитно-степные сообшества на склоне восточной экспозиции - петрофитно-разнотравно-ковыльная степь (Stipa capillata + Stipa pennata + Herbae stepposae), на склоне западной экспозиции - петрофитносолнцецветово-ковыльная степь (Stipa pennata + Helianthemum nummularium), на склоне южной экспозиции петрофитно-тимьяново-осоково-ковыльная степь (Stipa pulcherrima + Carex pediformis + Thymus zheguliensis). В исследованных сообществах произрастает 3 узколокальных эндемичных вида Жигулевской возвышенности: Euphorbia zhiguliensis, Gypsophila juzepczukii, Thymus zheguliensis и 3 субэндемичных вида: Festuca wolgensis s.str., Tanacetum sclerophyllum (эндемики Среднего Поволжья), Koeleria sclerophylla (эндемик Среднего Поволжья и Южного Урала); реликтовый элемент флоры представлен 3 видами: Alyssum lenense, Clausia aprica, Helianthemum nummularium. В Красную книгу Российской Федерации занесены 5 видов: Astragalus zingeri, Euphorbia zhiguliensis, Koeleria sclerophylla, Stipa pennata, Thymus zheguliensis; 16 видов - в Красную книгу Самарской области: Adonanthe vernalis, Alyssum lenense, Astragalus zingeri, Clausia aprica, Cotoneaster laxiflorus, Euphorbia zhiguliensis, Festuca wolgensis, Gypsophila juzepczukii, Helianthemum nummularium, Koeleria sclerophylla, Onosma volgensis, Pulsatilla patens, Scabiosa isetensis, Stipa pennata, Tanacetum sclerophyllum, Thymus zheguliensis. Наиболее распространенные растения петрофитных степей горы Могутова: Astragalus zingeri, Carex pediformis, Echinops ruthenicus, Galium hexanarium, Gypsophila juzepczukii, Helictotrichon desertorum, Jurinea ledebourii, Onosma volgensis, Psephellus carbonatus, Stipa pennata, Tanacetum sclerophyllum, Thesium ramosum, Thymus zheguliensis.

Ключевые слова: петрофитные (каменистые) степи; флоро-ценотические комплексы; редкие виды; эндемичные растения; реликтовые растения; Красная книга; гора Могутова; Жигулевская возвышенность; Самарская область.

Растительный покров Жигулевской возвышенности сложен лесными, степными, луговыми, скальными, прибрежно-водными и рудеральными сообществами. Степная растительность, развивающаяся на каменистых субстратах, представлена петрофитными (каменистыми) степями. Они имеют специфические черты и являются уникальным флоро-ценотическим комплексом. В Жигулевских горах растительные сообщества петрофитных степей формируются на известняковых обнажениях крутых склонов, тип почвы преимущественно карбо-литоземы темногумусовые типичные. Для них характерно большое разнообразие фитоценозов, высокая видовая насыщенность, присутствие эндемиков, вместе с нагорными сосняками данные степи признаются реликтовыми сообществами [1-4].

Гора Могутова - куполообразный эрозионный останец на севере Жигулевской возвышенности, расположена в национальном парке «Самарская Лука». Сообщества петрофитных степей формируются на известняковых обнажениях крутых склонов западной, южной и восточной экспозиций горы Могутова. Во флоре горы зарегистрировано более 670 видов сосудистых растений [5-9].

Растительные сообщества каменистых степей в Жигулевских горах по эколого-флористическому методу Ж. Браун-Бланке на основе описаний Л.М. Черепнина [10] в современной интерпретации относятся к классу Festuco-Brometea Br.-B1. et Tx. 1943, порядку Helictotricho-Stipetalia Toman $1969 \mathrm{em}$. Saitov in Saitov et Mirkin 1991, союзу Centaurenion sumensis Golub et Uzham. 1995 in Golub et al. 1995 [11; 12].

В конце мая 2013 г. нами проводились фитоценотические описания петрофитно-степных сообществ Могутовой горы на склонах разных экспозиций на пробных площадках $10 \times 10$ м (с минимальной антропогенной нагрузкой) по общепринятой методике с применением доминантного подхода (обилие видов по шкале Друде) [13-18]. Для каждого описания установлены географические координаты. Гербарные образцы хранятся в Институте экологии Волжского бассейна РАН (PVB). Номенклатура таксонов в основном стандартизирована по International Plant Names Index (http://www.ipni.org).
Ниже приводится характеристика пробных площадок внутри описанных сообществ петрофитных степей горы Могутова (табл. 1):

1) Петрофитно-разнотравно-ковыльная степь (Stipa capillata + Stipa pennata + Herbae stepposae), склон восточной экспозиции $\left(35^{\circ}\right), \quad \mathrm{N}$ 53²5'396", Е 49³1'283", 138 м н.ур.м. Общее проективное покрытие (ОПП) 75\%. Число видов на площадке: 41. В ней преобладают злаки, а из разнотравья выделяются: Potentilla glaucescens, Campanula sibirica, Centaurea pseudomaculosa, Echinops ruthenicus, Helictotrichon desertorum, Onosma volgensis.

2) Петрофитно-солнцецветово-ковыльная степь (Stipa pennata + Helianthemum nuтmularium), склон западной экспозиции (15²), N 53²5'193", Е 49²9'111", 193 м н.ур.м. Общее проективное покрытие (ОПП) 60\%. Число видов на площадке: 50. В сообществе, помимо доминирующих Stipa pennata и Helianthemum nummularium, большое число видов разнотравья.

3) Петрофитно-тимьяново-осоково-ковыльная степь (Stipa pulcherrima + Carex pediformis + Thymus zheguliensis), склон южной экспозиции $\left(35^{\circ}\right), \mathrm{N}$ 5324'598", Е 49³1'080", 120 м н.ур.м. Общее проективное покрытие (ОПП) 60\%. Число видов на площадке: 29. Доминируют Carex pediformis, Thymus zheguliensis, Stipa pulcherrima.

В изученных растительных сообществах произрастает 5 видов, занесенных в Красную книгу Российской Федерации [19; 20]: Astragalus zingeri, Euphorbia zhiguliensis, Koeleria sclerophylla, Stipa pennata, Thymus zheguliensis (Th. cimicinus auct. non p.p.); 16 видов Красной книги Самарской области [21; 22] с вышеперечисленными: Adonanthe vernalis, Alyssum lenense, Clausia aprica, Cotoneaster laxiflorus, Festuca wolgensis, Gypsophila juzepczukii, Helianthemum nummularium, Onosma volgensis, Pulsatilla patens, Scabiosa isetensis, Tanacetum sclerophyllum. В дополнительный список Красной книги Самарской области включены Helictotrichon desertorum, Polygala cretacea и Psephellus carbonatus.

В исследованных петрофитно-степных сообществах зарегистрировано 3 узколокальных эндемичных вида Жигулевской возвышенности: Euphorbia zhiguliensis, Gypsophila juzepczukii, Thymus zheguliensis и 3 
Сидякина Л.В., Васюков В.М., Саксонов С.В.

Петрофитно-степные сообщества горы Могутова..

03.02.00 - общая биология

субэндемичных вида: Festuca wolgensis s.str., Tanacetum sclerophyllum (эндемики Среднего Поволжья), Koeleria sclerophylla (эндемик Среднего Поволжья и Южного Урала) [23-25]. Реликтовый элемент флоры представлен 3 видами: Alyssum lenense, Clausia aprica, Helianthemum nummularium - плиоценовые горностепные реликты [26].

Доля синантропных растений в сообществах петрофитных степей незначительна и включает 7 апофитных видов (Acinos arvensis, Alyssum desertorum, Arenaria viscida, Centaurea pseudomaculosa, Draba lutea, Poa crispa, Verbascum lychnitis) и один адвентивный вид (Camelina microcarpa).

Виды, встречающиеся во всех трех изученных сообществах, являются типичными растениями петро-

фитных степей горы Могутова: Astragalus zingeri, Carex pediformis, Echinops ruthenicus, Galium hexanarium, Gypsophila juzepczukii, Helictotrichon desertorum, Jurinea ledebourii, Onosma volgensis, Psephellus carbonatus, Stipa pennata, Tanacetum sclerophyllum, Thesium ramosum, Thymus zheguliensis.

В описанных сообществах преобладающими жизненными формами из общего числа видов являются стержнекорневые и короткокорневищные травянистые поликарпики (гемикриптофиты), а из видов-доминантов на 1-й и 2-й пробных площадках - плотнодерновинные и стержнекорневые травянистые поликарпики (гемикриптофиты), на 3-й пробной площадке - плотнодерновинные травянистые поликарпики и полукустарнички (гемикриптофиты и хамефиты).

Таблица 1 - Фитоценотическая характеристика пробных площадок петрофитно-степных сообществ горы Могутова

\begin{tabular}{|c|c|c|c|c|c|c|}
\hline \multirow{2}{*}{ Виды растений } & \multicolumn{3}{|c|}{ Ассоциации } & \multirow{2}{*}{ ЖФ } & \multirow{2}{*}{ ЭЦГ } & \multirow{2}{*}{$Э Г$} \\
\hline & 1 & 2 & 3 & & & \\
\hline Acinos arvensis (Lam.) Dandy & $\mathrm{sp}$ & & & одн.; Т & сорн.-степ. & КМ \\
\hline Adonanthe vernalis (L.) Spach & & & $\mathrm{sp}$ & корн. мн.; Н & степ. & Мк \\
\hline Alyssum desertorum Stapf & & & $\mathrm{sp}$ & одн.; Т & сорн.-степ. & КМ \\
\hline Alyssum lenense Adams & $\mathrm{sp}$ & $\mathrm{sp}$ & & пкч.; C & петр.-степ. & Мк \\
\hline Arenaria viscida Hall. f. ex Lois. & $\mathrm{sp}$ & & & одн.; C & сорн. & КМ \\
\hline Artemisia marschalliana Spreng. & & sol & & пкч.; C & лес.-степ. & Мк \\
\hline Aster alpinus L. & & sol & & корн. мн.; Н & петр.-степ. & КМ \\
\hline Astragalus zingeri Korsh. & $\mathrm{sp}$ & un & sol & пкч.; $\mathrm{C}$ & петр.-степ. & К \\
\hline Bassia prostrata (L.) A.J. Scott & & un & & пкч.; $\mathrm{C}$ & степ. & К \\
\hline Bromopsis riparia (Rehm.) Holub & $\operatorname{cop}_{1}$ & & $\mathrm{sp}$ & рых.дерн. мн.; Н & лес.-степ. & КМ \\
\hline Camelina microcarpa Andrz. & sol & sol & & одн.; Т & сорн. & КМ \\
\hline Campanula sibirica $\mathrm{L}$. & $\operatorname{cop}_{1}$ & $\mathrm{sp}$ & & дв.; H & степ. & К \\
\hline Caragana frutex (L.) K. Koch & sol & $\mathrm{sp}$ & & куст.; $\mathrm{N}$ & степ. & КМ \\
\hline Carex pediformis C.A. Mey. & $\mathrm{sp}$ & $\mathrm{sp}$ & $\operatorname{cop}_{1}$ & пл.дерн. мн.; Н & петр.-степ. & Мк \\
\hline Centaurea pseudomaculosa Dobrocz. & $\operatorname{cop}_{1}$ & & sol & дв.; $\mathrm{H}$ & сор.-степ. & мк \\
\hline Clausia aprica (Steph.) Korn.-Tr. & $\mathrm{sp}$ & sol & & стержн. мн.; Н & петр.-степ. & мК \\
\hline Cotoneaster laxiflorus J. Jacq. ex Lindl. & & un & & куст.; $\mathrm{N}$ & петр.-степ. & К \\
\hline Draba lutea Gilib. ex DC. & $\mathrm{sp}$ & sol & & одн.; Т & оп.-луг. & $\mathrm{M}$ \\
\hline Echinops ruthenicus Bieb. & $\operatorname{cop}_{1}$ & $\mathrm{sp}$ & $\mathrm{sp}$ & стерж. мн.; Н & степ. & К \\
\hline Elytrigia lolioides (Kar. et Kir.) Nevski & & sol & & дл.; $\mathrm{H}$ & степ. & К \\
\hline Eremogone biebersteinii (Schlecht.) Holub & $\mathrm{sp}$ & & & корн. мн.; Н & псам.-ст. & мк \\
\hline Erysimum marschallianum Andrz. & & sol & & дв.-мн.; Н & лес.-степ. & КМ \\
\hline Euonymus verrucosus Scop. & & un & & куст.; N & лесн. & $\mathrm{M}$ \\
\hline Euphorbia seguierana Neck. & $\mathrm{sp}$ & $\mathrm{sp}$ & & корн. мн.; Н & петр.-степ. & Мк \\
\hline Euphorbia zhiguliensis (Prokh.) Prokh. & & un & & корнеот. мн.; Н & петр.-степ. & Мк \\
\hline Festuca valesiaca Gaud. & $\mathrm{sp}$ & & sol & пл.дерн. мн.; Н & степ. & К \\
\hline Festuca wolgensis P.A. Smirn. & & sol & & пл.дерн. мн.; Н & петр.-степ. & К \\
\hline Gagea podolica Schult. et Schult f. & & sol & & лук. мн.; G & степ. & Км \\
\hline Galatella villosa (L.) Rchb. f. & & $\mathrm{sp}$ & sol & кист. мн.; С & степ. & К \\
\hline Galium hexanarium Knjazev & $\mathrm{sp}$ & $\mathrm{sp}$ & sol & корн. мн., Н & петр.-степ. & К \\
\hline Gypsophila juzepczukii Ikonn. & sol & $\mathrm{sp}$ & $\mathrm{sp}$ & стержн. мн.; Н & петр.-степ. & К \\
\hline Helianthemum nummularium (L.) Mill. & & $\operatorname{cop}_{2}$ & $\mathrm{sp}$ & пкч; $\mathrm{C}$ & петр.-степ. & МК \\
\hline Helictotrichon desertorum (Less.) Nevski & $\operatorname{cop}_{1}$ & sol & sol & пл.дерн. мн.; Н & степ. & К \\
\hline Hieracium robustum Fr. & $\mathrm{sp}$ & & & корн. мн.; Н & степ. & К \\
\hline Jurinea ledebourii Bunge & $\mathrm{sp}$ & sol & sol & стержн. мн.; Н & степ. & К \\
\hline Koeleria sclerophylla P.A. Smirn. & & $\mathrm{sp}$ & $\mathrm{sp}$ & пл.дерн. мн.; Н & петр.-степ. & МК \\
\hline $\begin{array}{l}\text { Melampyrum argyrocomum (Fisch. ex Ledeb.) } \\
\text { Kos.-Pol. }\end{array}$ & & $\mathrm{sp}$ & sol & п-параз. одн.; Т & степ. & КМ \\
\hline Melica transsilvanica Schur & & sol & & рых.кус. мн.; Т & петр.-степ. & МК \\
\hline
\end{tabular}




\begin{tabular}{|c|c|c|c|c|c|c|}
\hline Onosma volgensis Dobrocz. & $\operatorname{cop}_{1}$ & $\mathrm{sp}$ & $\mathrm{sp}$ & пкч.; C & петр.-степ. & $\kappa$ \\
\hline Pilosella echioides (Lumn.) F.Schult et Sch. Bip. & sol & sol & & кист. мн.; Н & лес.-степ. & MK \\
\hline Poa angustifolia $\mathrm{L}$. & sol & & & рых.дерн. мн.; Н & лес.-степ. & мК \\
\hline Poa crispa Thuill. & & $\mathrm{sp}$ & sol & рых.дерн. мн.; Н & степ. & К \\
\hline Poa tranbaicalica Roshev. & $\mathrm{sp}$ & & & рых.дерн. мн.; Н & петр.-степ. & Мк \\
\hline Polygala cretacea Kotov & & & sol & стержн. мн.; Н & петр.-степ. & Км \\
\hline Polygonatum odoratum (Mill.) Druce & & sol & & корн. мн.; G & лесн. & $\mathrm{M}$ \\
\hline Potentilla glaucescens Willd. ex Schlecht & $\operatorname{cop}_{2}$ & & $\mathrm{sp}$ & корн. мн.; Н & петр.-степ. & K \\
\hline Psephellus carbonatus (Klokov) Greuter & $\mathrm{sp}$ & $\mathrm{sp}$ & $\mathrm{sp}$ & корн. мн.; Н & петр.-степ. & K \\
\hline Pseudolysimachion incanum (L.) Holub & $\mathrm{sp}$ & & & корн. мн.; Н & степ. & К \\
\hline Pulsatilla patens (L.) Mill. & & sol & & корн. мн.; Н & оп.-псам. & км \\
\hline Salvia stepposa Shost. & $\mathrm{sp}$ & & $\mathrm{sp}$ & стержн. мн.; Н & степ. & Мк \\
\hline Scabiosa isetensis L. & & sol & sol & пкч; C & петр.-степ. & MK \\
\hline Scabiosa ochroleuca L. & $\mathrm{sp}$ & $\mathrm{sp}$ & & стержн. мн.; Н & степ. & км \\
\hline Scorzonera austriaca Willd. & & sol & & стерж. мн.; H & петр.-степ. & мк \\
\hline Scorzonera purpurea L. & sol & sol & & стержн. мн.; Н & лес.-степ. & МК \\
\hline Scorzonera stricta Hornem. & sol & & & стержн. мн.; H & степ. & MK \\
\hline Stipa capillata $\mathrm{L}$. & $\mathrm{cop}_{2}$ & sol & & пл.дерн. мн.; Н & степ. & K \\
\hline Stipa pennata L. & $\operatorname{cop}_{2}$ & $\operatorname{cop}_{2}$ & $\mathrm{sp}$ & пл.дерн. мн.; Н & степ. & К \\
\hline Stipa pulcherrima K. Koch & & $\mathrm{sp}$ & $\operatorname{cop}_{2}$ & пл.дерн. мн.; Н & степ. & мк \\
\hline Tanacetum sclerophyllum (Krasch.) Tzvelev & $\mathrm{sp}$ & sol & sol & корн. мн., Н & петр.-степ. & K \\
\hline Taraxacum erythrospermum Andrz. s.l. & $\mathrm{sp}$ & & & стержн. мн.; Н & луг.-степ. & M \\
\hline Thalictrum flexuosum Bernh. ex Rchb. & & sol & & корн. мн.; Н & степ. & KM \\
\hline Thesium ramosum Hayne & $\mathrm{sp}$ & $\mathrm{sp}$ & sol & п-параз. стерж. мн.; G & степ. & MK \\
\hline Thymus marschallianus Willd. & sol & & & пкч.; $\mathrm{C}$ & луг.-степ. & км \\
\hline Thymus zheguliensis Klokov et Shost. & $\mathrm{sp}$ & $\mathrm{sp}$ & $\operatorname{cop}_{1}$ & пкч.; $\mathrm{C}$ & петр.-степ. & K \\
\hline Tragopogon major Jacq. & sol & & & дв.; $\mathrm{H}$ & луг.-степ. & Мк \\
\hline Trinia multicaulis (Poir.) Schischk. & & $\mathrm{sp}$ & & дв.; $\mathrm{H}$ & степ. & мк \\
\hline Verbascum lychnitis L. & & un & & дв.-мН.; Н & луг.-степ. & МК \\
\hline Vincetoxicum stepposum (Pobed.) A. et D. Love & & sol & sol & корн. мн.; Н & степ. & MK \\
\hline Viola ambigua Waldst. et Kit. & sol & sol & & стержн. мн.; Н & степ. & $\kappa$ \\
\hline
\end{tabular}

Примечание: ЖФ - жизненная форма по И.Г. Серебрякову [27] и Р. Раункиеру [28]: куст. - кустарник, пк. полукустарник, пкч. - полукустраничек, мн. - многолетний травянистый поликарпик, дв.-мн. - дву- или многолетний травянистый монокарпик, дв. - двулетний травянистый монокарпик, одн. - однолетник, кист. - кистекорневой, корн. - корневищный, корнеот. - корнеотпрысковый, лук. - луковичный, п-параз. - полупаразитный, пл.дерн. - плотнокустовой, рых.дерн. - рыхлодерновинный, стержн. - стержнекорневой; $\mathrm{N}$ - нанофанерофит, $\mathrm{H}$ - гемикриптофит, $\mathrm{C}$ - хамефит, $\mathrm{G}$ - геофит, $\mathrm{T}$ - терофит. ЭЦГ - эколого-ценотическая группа: лесн. - лесной, лес.-степ. - лесостепной, луг.-степ. - лугово-степной, оп.-луг. - опушечно-луговой, оп.-псам. опушечно-псаммофитный, петр.-степ. - петрофитно-степной, сорн. - сорный, сорн.-ст. - сорно-степной, степ. - степной, псам.-степ. - псаммофитно-степной. ЭК - экологическая группа: к - ксерофит, м - мезофит, км ксеромезофит, мк - мезоксерофит.

Преобладающими эколого-ценотическими группами для видов трех сообществ примерно в равной степени являются степные и петрофитно-степные. У типичных растений петрофитных степей горы Могутова доля петрофитно-степной группы составляет $62 \%$, а степной $-38 \%$.

Среди преобладающих экологических групп по увлажнению в исследованных сообществах доля ксерофитов немного выше, чем мезоксерофитов. Процент ксерофитов в группе типичных растений петрофитных степей составляет $85 \%$, а мезоксерофитов $-15 \%$.

Несмотря на наличие общих закономерностей распределения петрофитно-степных сообществ на склонах горы Могутова, каждое из них обладает своей собственной спецификой.

Необходимы мониторинговые исследования петрофитно-степных сообществ как резервата редких, эндемичных и реликтовых растений Жигулевской возвышенности.

\section{СПИСОК ЛИТЕРАТУРЫ:}

1. Абакумов Е.В., Бакиев А.Г., Васюков В.М. Могутова гора и ее окрестности: Подорожник / под ред. С.В. Саксонова и С.А. Сенатора. Тольятти: Кассандра, 2013. $134 \mathrm{c}$

2. Абакумов Е.В., Гагарина Э.И. Почвы Самарской Луки: разнообразие, генезис, охрана. СПб.: СПбГУ, 2008. 155 с.

3. Кудинов К.А. Жигулевский заповедник. Тольятти: Принс-С, 2007. 126 с.

4. Саксонов С.В. Самаролукский флористический феномен. М.: Наука, 2006. 263 с.

5. Ильина В.Н. Современное состояние растительного покрова уникального природного объекта «Могутова гора» (Самарская Лука, Жигули) // Самарская Лука: проблемы региональной и глобальной экологии. 2010. Т. 19, № 1. С. 137-155.

6. Саксонов С.В., Сенатор С.А. Дополнения к локальной флоре «Могутова гора» (Самарская Лука, 
Жигули) // Самарская Лука: проблемы региональной и глобальной экологии. 2010. Т. 19, № 2. С. 162-169.

7. Саксонов С.В., Сенатор С.А., Раков Н.С., Куликов П.В. Второе дополнение к локальной флоре «Могутовая гора» (Самарская Лука, Жигули) // Самарская Лука: проблемы региональной и глобальной экологии. 2010. Т. 19, № 4. С. 142-150.

8. Саксонов С.В., Сенатор С.А., Раков Н.С., Васюков В.М. Сосудистые растений Могутовой горы (Жигулевская возвышенность, Самарская область) // Фиторазнообразие Восточной Европы. 2013. Т. 7, № 1. C. $47-68$.

9. Сенатор С.А., Саксонов С.В., Раков Н.С., Васюков В.М., Сидякина Л.В. Список сосудистых растений г. Жигулевска и окрестностей (национальный парк «Самарская Лука», Самарская область) // Могутова гора и ее окрестности: Подорожник / под ред. C.В. Саксонова и С.А. Сенатора. Тольятти: Кассандра, 2013. С. 102-127.

10. Черепнин Л.М. Растительность каменистых степей Жигулевских гор: дис. ... канд. биол. наук. Рукопись, 1941. 365 с.

11. Голуб В.Б., Саксонов С.В., Ужамецкая Е.А. Характеристика каменистых степей Жигулевских гор (по материалам исследований Л.М. Черепнина) // Самарская Лука: Бюл. Самара, 1995. № 6/95. С. 73-96.

12. Ужамецкая Е.А., Саксонов С.В. Некоторые итоги классификации растительных сообществ каменистых степей Жигулевских гор // Самарская Лука на пороге третьего тысячелетия: Материалы к докладу «Состояние природного и культурного наследия Самарской Луки». Тольятти: ИЭВБ РАН, 1999. С. 103-105.

13. Юнатов А.А. Типы и содержание геоботанических исследований. Выбор пробных площадей и заложение экологических профилей // Полевая геоботаника. Т. 3 / под общ. ред. Е.М. Лавренко и А.А. Корчагина. М.; Л.: Наука, 1964. С. 9-35.

14. Воронов А.Г. Геоботаника: учеб. пособие для ун-тов и пед. ин-тов. Изд. 2-е, испр. и доп. М.: Высшая школа, 1973. 384 с.

15. Вальтер Г. Общая геоботаника: Пер. с нем. / перевод и пред. А.Г. Еленевского. М.: Мир, 1982. $264 \mathrm{c}$.

16. Нешатаев Ю.Н. Методы анализа геоботанических материалов: учеб. пособие. Л.: Изд-во Ленингр. ун-та, 1987. $192 \mathrm{c.}$
17. Ипатов В.С. Методы описания фитоценоза. СПб.: СПбГУ, 2000. 56 с.

18. Ипатов В.С., Мирин Д.М. Описание фитоценоза: Мет. рекомендации. СПб.: СПбГУ, 2008. 71 с.

19. Красная книга Российской Федерации (растения и грибы). М.: Тов-во науч. изд. КМК, 2008. 855 с.

20. Сидякина Л.В. Особо охраняемые растения горы Могутова (Самарская область) I. Федеральная Красная книга // Известия Самар. науч. центра РАН. 2013. T. 15, № 3(7). С. 2133-2138.

21. Красная книга Самарской области. Т. 1. Редкие виды растений, лишайников и грибов / под ред. чл.корр. РАН Г.С. Розенберга и проф. С.В. Саксонова. Тольятти: ИЭВБ РАН, 2007. 372 с.

22. Сидякина Л.В., Васюков В.М. Особо охраняемые растения горы Могутова (Самарская область) II. Красная книга Самарской области // Известия Самар. науч. центра РАН. 2014. Т. 16. № 5. С. 134-142.

23. Васюков В.М. Эндемизм флоры Приволжской возвышенности // Флористические исследования в Средней России: Материалы VI науч. совещ. по флоре Средней России (Тверь, 15-16 апреля 2006 г.). М.: Тов-во науч. изд. КМК, 2006. С. 36-39.

24. Васюков В.М., Саксонов С.В., Сенатор С.А. Эндемичные растения бассейна Волги // Фиторазнообразие Восточной Европы. 2015. Т. 9, № 3. С. 27-44.

25. Сидякина Л.В., Костина М.А., Васюков В.М. Флористическая оценка территории Самарской области по эндемичным видам // Инновационные подходы к обеспечению устойчивого развития социо-экологоэкономических систем: Материалы II междунар. конф. (Самара-Тольятти, 20-21 мая 2015 г.). Самара: Самар. гос. экон. ун-т, 2015. С. 94-98.

26. Сенатор С.А., Саксонов С.В. Средне-Волжский биосферный резерват: раритетный флористический комплекс / под ред. чл.-корр. РАН Г.С. Розенберга; послесл. к.б.н. Ю.К. Рощевский. Тольятти: Кассандра, 2010. 251 с.

27. Серебряков И.Г. Жизненные формы высших растений и их изучение // Полевая геоботаника / под общ. ред. Е.М. Лавренко и А.А. Корчагина. М.; Л.: Наука, 1964. Т. 3. С. 146-205.

28. Raunkier Ch. Plant life forms. Oxford: Clarendon Press, 1937. 104 p.

Исследование поддержано грантами РФФИ № 15-44-02160 р_поволжье_a, № 14-04-97072 р_поволжне_а.

\section{PETROPHYTIC-STEPPE COMMUNITIES OF THE MOGUTOVA MOUNTAIN (ZHIGULI HILLS)}

(C) 2016

L.V. Sidyakina, postgraduate student of the Laboratory of Problems of Phytodiversity

V.M. Vasjukov, candidate of biological sciences, researcher of the Laboratory of Problems of Phytodiversity

S.V. Saksonov, doctor of biological sciences, professor, deputy director for scientific work, head of the Laboratory of Problems of Phytodiversity

Institute of Ecology of the Volga River Basin of Russian Academy of Sciences, Togliatti (Russia)

Abstract. The Mogutova Mountain - domal erosive ostanets in the north of the Zhigulyovsk hill, lies in national park «Samara Luka». Communities petrophytic steppes are formed on calcareous exposures of steep slopes of the western, southern and east expositions of the mountain Mogutova. Petrophytic-steppe communities on a slope of east exposition are described - petrophytic-forbs-feather grass steppe (Stipa capillata + Stipa pennata + Herbae stepposae), on a slope of west exposition - petrophytic-sunrose-feather grass steppe (Stipa pennata + Helianthemum nummularium), on a slope of south exposition - petrophytic-thyme-sedge-feather grass steppe (Stipa pulcher- 
rima + Carex pediformis + Thymus zheguliensis). In the studied communities three narrow-local of endemic species of the Zhigulyovsk hill grows: Euphorbia zhiguliensis, Gypsophila juzepczukii, Thymus zheguliensis and three of subendemic species grows: Festuca wolgensis s.str., Tanacetum sclerophyllum (endemics of Central Volga area), Koeleria sclerophylla (endemic of Central Volga area and South Ural); the relict element of flora is presented by three species: Alyssum lenense, Clausia aprica, Helianthemum nummularium. Five species are included in the Red book of the Russian Federation: Astragalus zingeri, Euphorbia zhiguliensis, Koeleria sclerophylla, Stipa pennata, Thymus zheguliensis; sixteen species are included in the Red book of the Samara region: Adonanthe vernalis, Alyssum lenense, Astragalus zingeri, Clausia aprica, Cotoneaster laxiflorus, Euphorbia zhiguliensis, Festuca wolgensis, Gypsophila juzepczukii, Helianthemum nummularium, Koeleria sclerophylla, Onosma volgensis, Pulsatilla patens, Scabiosa isetensis, Stipa pennata, Tanacetum sclerophyllum, Thymus zheguliensis. The most widespread plants of petrophytic steppes of the Mogutova Mountain: Astragalus zingeri, Carex pediformis, Echinops ruthenicus, Galium hexanarium, Gypsophila juzepczukii, Helictotrichon desertorum, Jurinea ledebourii, Onosma volgensis, Psephellus carbonatus, Stipa pennata, Tanacetum sclerophyllum, Thesium ramosum, Thymus zheguliensis.

Keywords: petrophytic steppes; stone steppes; floro-coenotic complexes; rare species; endemic plants; relict plants; Red book; Mogutova Mountain; Zhigulyovsk hills; Samarskaya Luka; Zhiguli Nature Reserve; Samara Region.

УДК 631.461, 631.467

\title{
ИССЛЕДОВАНИЕ МИКРОФЛОРЫ ПОЧВ В ЛЕСНЫХ ПИТОМНИКАХ ВОЛОГОДСКОЙ ОБЛАСТИ
}

(C) 2016

С.М. Хамитова, кандидат сельскохозяйственных наук, доцент кафедры геоэкологии и инженерной геологии Ю.М. Авдеев, кандидат сельскохозяйственных наук, доцент кафедры геоэкологии и инженерной геологии

B.С. Снетилова, магистрант кафедры геоэкологии и инженерной геологии Вологодский государственный университет, Вологда (Россия)

\begin{abstract}
Аннотаџия. Почва - это самостоятельный природный объект, подлежащий охране, диктует приоритет обеспечения сохранения почв при осуществлении хозяйственной или иной деятельности. На современном этапе развития общества увеличиваются масштабы урбосистемы. Окружающая среда на городских территориях подвергаются различным изменениям вследствие интенсивной антропогенной нагрузки. Состояние почвенного покрова городских территорий требует пристального внимания, так как воздействие транспортной системы, промышленного производства, строительной сферы оказывает постоянное давление на почвенную среду, изменяя практически все ее компоненты, начиная с агрохимических и физических свойств и заканчивая микробиологическими и биохимическими параметрами, лишая почвенный покров в городах способности выполнять важные экологические функции. Микробиота, биохимические параметры почвы, ее биологическая активность под влиянием антропогенного воздействия изменяются в первую очередь, поэтому считаются многими исследователями наиболее чувствительными к загрязнению показателями состояния почвенного покрова. В городских ландшафтах интересное и важное для города и населения место занимают территории, занятые зелеными насаждениями. Часто эти зоны городов выпадают из поля зрения исследователей, так как традиционно считается, что почвы этих территорий не подвергаются интенсивному антропогенному воздействию и преобразованию, а, следовательно, уровень загрязнения таких экосистем невысок, то есть их состояние не должно вызывать опасений. Между тем небольшие по площади рекреационные территории в пределах города часто испытывают сильное техногенное влияние, в результате ухудшается состояние растительности и почвы этих территорий. В то время как рекреационные территории города играют важную роль в оздоровлении окружающей среды, выполняя важнейшие рекреационные и санитарно-гигиенические функции. Учитывали почвенные грибы, актиномицеты и бактерии методом предельных разведений и глубинного посева почвенной суспензии на плотные питательные среды.

Ключевые слова: Почва; микроорганизмы почвы; микробиота; почвенные грибы; актиномицеты; бактерии; фитопатогены; городские зелёные насаждения; урбанизированная среда; антропогенное воздействие; окружающая среда; рекреационные территории; загрязнение; рекреационные и санитарно-гигиенические функции.
\end{abstract}

Городской почвенный покров является уникальным местообитанием микроорганизмов, что находит свое отражение в биогеохимических циклах биофильных элементов крупных городов $[1 ; 2]$. Микроорганизмы чутко реагируют на изменения различной природы, происходящие в окружающей среде, что определяет большую подвижность и динамичность микробиологических показателей [3; 4]. Микроорганизмы почвы в процессе своего существования испытывают влияние целого комплекса природных абиотических, биотических, а также антропогенных и техногенных факторов [5-15]. На первых этапах разложения растительных остатков на них начинают развиваться неспорообразующие бактерии и грибы. Затем возрастает численность бацилл и актиномицетов [16-22].

Интерес к ризосфере обусловлен важностью этой зоны как граничной в системе почва-растение [23]. Многие, содержащиеся в почве микроорганизмы, являются фитопатогенами [24; 25]. Растение оказывает непосредственное воздействие на микроорганизмы прикорневой зоны. Многие агрофизические, агрохимические методы повышения продуктивности растений сводятся к воздействию на ризосферную микрофлору [26-28]. 